\title{
Synthesis, characterization and biocidal properties of platinum metal complexes derived from 2,6-diacetylpyridine (bis thiosemicarbazone)
}

\author{
Monika Tyagi, Sulekh Chandra \\ Department of Chemistry, Zakir Husain Delhi College, University of Delhi, New Delhi, India \\ Email: schandra00@yahoo.com, mnk02tyg@yahoo.co.in
}

Received 21 February 2012; revised 24 March 2012; accepted 2 April 2012

\begin{abstract}
The coordination compounds of $\mathrm{Pd}^{\mathrm{II}}, \mathrm{Pt}^{\mathrm{II}}, \mathrm{Rh}^{\mathrm{III}}$ and Ir ${ }^{\mathrm{III}}$ metal ions with a Schiff base ligand (L) i.e. 2,6diacetylpyridine bis(thiosemicarbazone) have been synthesized and characterized by elemental analyses, molar conductance, magnetic susceptibility measurements, IR, NMR and electronic spectral studies. On the basis of molar conductance and elemental analyses the complexes were found to have composition $[\mathrm{M}(\mathrm{L})] \mathrm{Cl}_{2}$ and $\left[\mathrm{M}^{\prime}(\mathrm{L}) \mathrm{Cl}\right] \mathrm{Cl}_{2}$, where $\mathrm{M}=\mathbf{P d}(\mathrm{II}), \operatorname{Pt}(\mathrm{II})$ and $M^{\prime}=\operatorname{Rh}($ III), Ir(III). The spectral studies reveal that the complexes possess monomeric composition. Complexes of $\mathrm{Pd}^{\mathrm{II}}$ and $\mathrm{Pt}^{\mathrm{II}}$ were found to have four coordinated square planar geometry whereas the complexes of $R^{\mathrm{III}}$ and $\mathrm{Ir}^{\mathrm{III}}$ posses six coordinated octahedral geometry. The ligand field parameters were calculated using various energy level diagrams. In vitro synthesized compounds and metal salts have been tested against some species of plant pathogenic fungi and bacteria in order to assess their antimicrobial properties.
\end{abstract}

Keywords: Schiff Base; Platinum Metal Complexes; Spectral Studies; Biological Screening

\section{INTRODUCTION}

Schiff's bases are widely studied because of increasing recognition in biological systems [1]. Schiff's bases and their complexes are used in some chemical processes as catalysts. They are also used in biological models to understand the structure of bio-molecules [2]. Schiff bases derived from thiosemicarbazide and their metal complexes are of great significance for their pharmacological properties such as antibacterial, antifungal, antitumoral, antiviral and anticancer [3-9]. After the discovery of the chemotherapeutically active cisplatin large number of metal complexes with thiosemicarbazide derivatives were synthesized [10]. It is well known that several metal ions enhance the biological activities of thiosemicarbazone particularly the metals of platinum groups. The chemistry of rhodium and iridium has been receiving considerable current attention largely because of the interesting chemical properties exhibited by the complexes of these two metals [11]. Though neither of these two metals are bio-essential elements but their compounds have useful applications in the biological field [12]. Due to the growing interest of palladium, platinum, rhodium and iridium metal complexes of thiosemicarbazones, here we report the synthesis, characterization and biological activities of $\mathrm{Pd}(\mathrm{II}), \mathrm{Pt}(\mathrm{II}), \mathrm{Rh}(\mathrm{III})$ and Ir(III) complexes of Schiff base ligand derived from 2,6-diacetylpyridine and thiosemicarbazide. The results obtained from antimicrobial activities were compared with standard antifungal drug: Amphotericin-B and antibiotic: Streptomycin.

\section{CHEMISTRY}

All the chemicals used were of Anala $\mathrm{R}$ grade and procured from Sigma-Aldrich and Fluka. Metal salts were purchased from E. Merck and were used as received. They include $\mathrm{PdCl}_{2}, \mathrm{PtCl}_{2}, \mathrm{RhCl}_{2}, \mathrm{RuCl}_{2}$, 2,6-diacetylpyridine and thiosemicarbazide. The solvents used were ethanol, deutrated dimethyl sulfoxide (d6-DMSO), acetone and benzene.

\subsection{Synthesis of the Ligand (L)}

The ligand L was prepared by the mixing of hot ethanolic solution $(20 \mathrm{~mL})$ of thiosemicarbazide $(1.82 \mathrm{~g}, 0.02$ $\mathrm{mol})$ and an ethanolic solution $(20 \mathrm{~mL})$ of 2,6-diacetylpyridine $(1.63 \mathrm{~g}, 0.01 \mathrm{~mol})$ with constant stirring in the presence of few drops of conc. $\mathrm{HCl}$. This mixture was refluxed for $2 \mathrm{~h}$ at $80^{\circ} \mathrm{C}$ and then allowed to cool overnight at $0^{\circ} \mathrm{C}$. The isolated light yellow colored precipitate was filtered. It was washed with cold $\mathrm{EtOH}$ and dried under vacuum over $\mathrm{P}_{4} \mathrm{O}_{10}$. Yield $(67 \%)$, mp $265^{\circ} \mathrm{C}$. Element chemical analysis data is shown in Table 1. The 
scheme of synthesis of ligand is shown in Figure 1.

\subsection{Synthesis of $\operatorname{Pd}(\mathrm{II})$ and $\operatorname{Pt}(\mathrm{II})$ Complexes}

Hot ethanolic solution $(20 \mathrm{~mL})$ of ligand $(1 \mathrm{mmol})$ and hot ethanolic solution $(20 \mathrm{~mL})$ of the corresponding metal salts $(1 \mathrm{mmol})$ was mixed with continuous stirring. The resulting solution was refluxed for $6-8 \mathrm{~h}$ at $85^{\circ} \mathrm{C}$. On cooling the colored product was precipitated out. It was filtered, washed with cold ethanol and dried under vacuum. Purity of the complexes were checked by TLC.

\subsection{Synthesis of $R h(I I I)$ and $\operatorname{Ir}($ III) Complexes}

A hot ethanolic solution $(20 \mathrm{~mL})$ the ligand $(1 \mathrm{mmol})$ was added slowly to the hot ethanolic solution $(20 \mathrm{~mL})$ of the corresponding metal salts $(1 \mathrm{mmol})$ with continuous stirring. The resultant colored solution was refluxed for $10-12 \mathrm{~h}$ at $80^{\circ} \mathrm{C}$. On cooling the colored precipitate of complex was obtained, which was filtered, washed thoroughly with cold ethanol and dried under vacuum. Purity of the complexes were checked by TLC.

\subsection{Physical Measurements}

$\mathrm{C}, \mathrm{H}$ and $\mathrm{N}$ contents were analyzed on a Carlo-Erba 1106 elemental analyzer. NMR spectra were recorded with a model Bruker Avance DPX-300 spectrometer operating at $300 \mathrm{MHz}$ using DMSO- $\mathrm{d}_{6}$ using as a solvent and TMS as an internal standard. IR spectra were recorded as CsI discs on FT-IR spectrum BX-II spectrophotometer. The electronic spectra were recorded on Shimadzu UV mini1240 spectrophotometer using DMSO as a solvent. The molar conductance of complexes was measured on the ELICO (CM82T) conductivity bridge. Magnetic susceptibility was measured at room temperature on a Gouy balance using $\mathrm{CuSO}_{4} \cdot 5 \mathrm{H}_{2} \mathrm{O}$ as a calibrant.

\section{PHARMACOLOGY}

\subsection{Test Microorganisms}

Some fungal species i.e. Aspergillus niger, Aspergillus fumigates, Fusarium odum and bacterial species i.e. Staphyloccocus aureus, Escherichia coli were screened for antifungal and antibacterial activities of the synthesized compounds.

\subsection{Medium}

Two solid media namely Potato Dextrose Agar (PDA) (for fungus) and Nutrient agar (NA) (for bacteria) were used for antimicrobial assay.

Table 1. Elemental analyses and molar conductance for $\mathrm{Pd}(\mathrm{II}), \mathrm{Pt}(\mathrm{II}), \mathrm{Rh}(\mathrm{III})$ and $\mathrm{Ir}(\mathrm{III})$ complexes with investigated ligand.

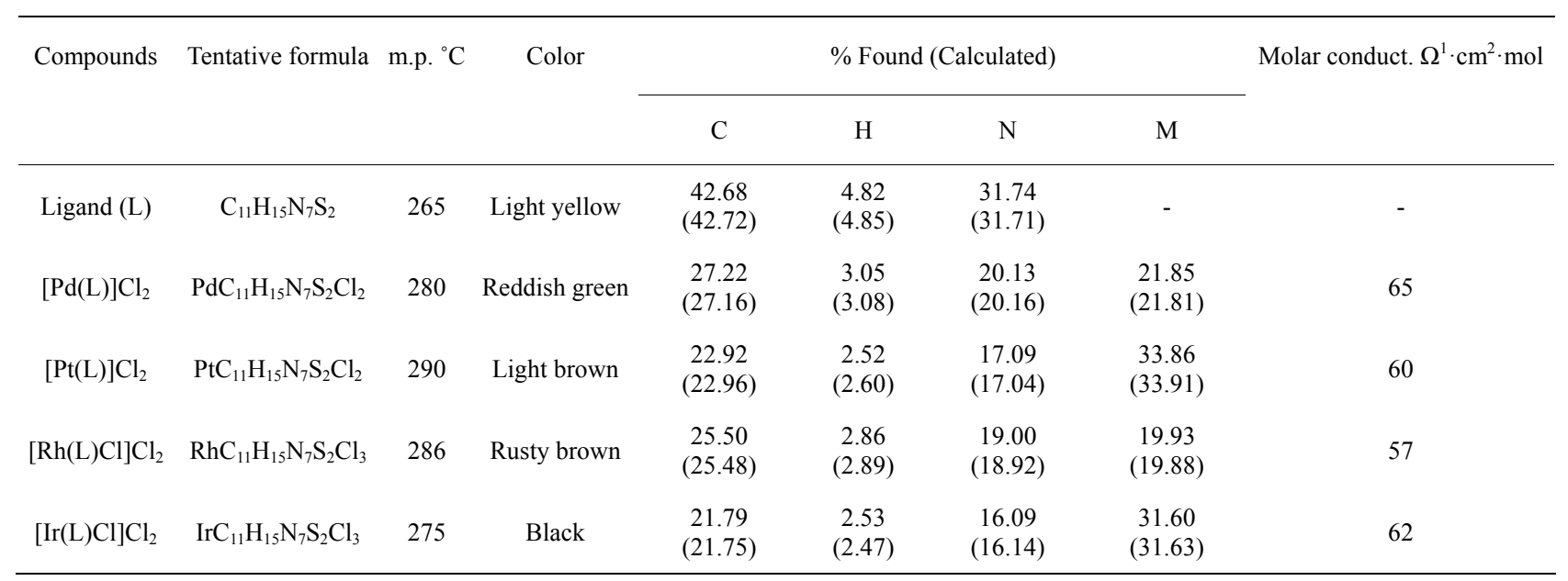<smiles>C=C(C)c1cccc(C(C)=O)n1</smiles><smiles>C/C(=N\NC(N)=S)c1cccc(/C(C)=N/NC(N)=S)n1</smiles>

Figure 1. Synthesis of ligand (L). 


\subsection{In Vitro Antimicrobial Activity}

\subsubsection{Antifungal Screening}

The preliminary fungitoxicity screening of the compounds at different concentrations were performed using Food Poison Method [13,14]. Stock solutions of compounds were prepared by dissolving the compounds in DMSO. Amphotericin-B used as antifungal drug and DMSO served as control. Potato dextrose agar medium was prepared by using potato, dextrose, agar-agar and distilled water. Appropriate quantities of the compounds in DMSO was added to potato dextrose agar medium in order to get a concentrations of 100, 200 and 300 ppm of compound in the medium. The medium was poured into a set of two petriplates under aseptic conditions in a laminar flow hood. When the medium in the plates was solidified, a mycelial discs of $0.5 \mathrm{~cm}$ in diameter cut from the periphery of the 7 days old culture and it was aseptically inoculated upside down in the centre of the petriplates. These treated petriplates were incubated at $26^{\circ} \mathrm{C} \pm 1{ }^{\circ} \mathrm{C}$ until fungal growth in the control petriplates was almost complete.

The mycelial growth of fungi $(\mathrm{mm})$ in each petriplates was measured diametrically and growth inhibition (I) were calculated by using the formula:

$$
\mathrm{I}(\%)=\frac{\mathrm{C}-\mathrm{T}}{\mathrm{C}} \times 100
$$

where 90 is the diameter $(\mathrm{mm})$ of the petriplates, and C is the growth of the fungus ( $\mathrm{mm}$ ) in control and $\mathrm{T}$ is the growth of test compounds.

\subsubsection{Antibacterial Screening}

The antibacterial activities were evaluated by the Disc Diffusion Method using nutrient agar medium $[15,16]$. Nutrient agar medium was prepared by using peptone, beef extract, $\mathrm{NaCl}$, agar-agar and distilled water. The test compounds in measured quantities were dissolved in DMSO to get a concentrations of 100, 200 and $300 \mathrm{ppm}$ of compounds. $25 \mathrm{~mL}$ nutrient agar media (NA) was poured in each petriplates. After solidification $0.1 \mathrm{~mL}$ of test bacteria spreads over the medium using a spreader. The disc of Whatmann no 1 filter paper having the diameter $5.00 \mathrm{~mm}$ each containing $\left(1.5 \mathrm{mg} \cdot \mathrm{cm}^{-1}\right)$ of compounds were placed at 4 equidistant places at a distance of $2 \mathrm{~cm}$ from the center in the inoculated petriplates. Filter paper disc treated with DMSO served as control and Streptomycin used as a standard drug. All determination were made in duplicate for each of the compounds. Average of two independent readings for each compounds was recorded. These petriplates were kept in refrigerator for $24 \mathrm{hrs}$ for Pre-diffusion. Finally petriplates were incubated for $26-30 \mathrm{~h} 28^{\circ} \mathrm{C} \pm 2^{\circ} \mathrm{C}$. The zone of inhibition was calculated in mm carefully.

\section{RESULTS AND DISCUSSION}

The stoichiometric data of complexes reveal that the complexes have 1:1 metal to ligand ratio. The formation of metal complexes is expressed by the following chemical equation:

$$
\begin{gathered}
\mathrm{L}+\mathrm{MCl}_{2} \stackrel{\text { Reflux }}{\longrightarrow} \mathrm{LMCl}_{2} \\
\mathrm{~L}+\mathrm{M}^{\prime} \mathrm{Cl}_{3} \stackrel{\text { Reflux }}{\longrightarrow} \mathrm{LM}^{\prime} \mathrm{Cl}_{3}
\end{gathered}
$$

where $\mathrm{L}=$ 2,6-diacetylpyridine bis(thiosemicarbazone) and $\mathrm{M}=\mathrm{Pd}(\mathrm{II}), \operatorname{Pt}(\mathrm{II}) ; \mathrm{M}^{\prime}=\mathrm{Rh}(\mathrm{III})$ and $\mathrm{Ir}(\mathrm{III})$. On the basis of elemental analysis, the complexes were found to have the composition as given in Table 1. The analytical data are in a good agreement with the proposed stoichiometry of the complexes. These complexes are air-stable, insoluble in $\mathrm{H}_{2} \mathrm{O}$ and most of organic solvents, but soluble in DMSO and DMF. Molar conductance values of $\mathrm{Pd}(\mathrm{II})$ and $\mathrm{Pt}(\mathrm{II})$ complexes in DMSO solution correspond to 1:2 electrolytic nature whereas $\mathrm{Rh}(\mathrm{III})$ and $\mathrm{Ir}(\mathrm{III})$ complexes correspond 1:1 electrolyte nature [17]. Thus these complexes may be formulated as $[\mathrm{M}(\mathrm{L})] \mathrm{Cl}_{2}$ and $\left[\mathrm{M}^{\prime}(\mathrm{L}) \mathrm{Cl}\right] \mathrm{Cl}_{2}$.

\subsection{Mass Spectrum}

The mass spectrum of ligand displays the parental ion peak $\left(\mathrm{M}^{+}\right)$at $\mathrm{m} / \mathrm{z}=309(78 \%)$ and a weak peak at $\mathrm{m} / \mathrm{z}=$ 310 due to ${ }^{13} \mathrm{C}$ and ${ }^{15} \mathrm{~N}$ isotopes. The peak at $\mathrm{m} / \mathrm{z}=79$ $(100 \%)$ is due to pyridine ring. The other positive ions give the peaks at 295, 248, 193, 170,121, 85, 70 and 16 mass numbers. The intensities of these peaks give the idea of the stabilities of the fragments.

\subsection{NMR Spectra}

The ${ }^{1} \mathrm{H}$ NMR spectra of Schiff base ligand and its metal complexes were recorded in DMSO- $\mathrm{d}_{6}$ and are given in Table 2. The resonance for two methyl groups appeared as a singlet at $\delta 2.27 \mathrm{ppm}$ in the ligand and no significant change was observed in complexes $\mathrm{s}$ [18]. In the ligand a sharp singlet at $\delta 2.48 \mathrm{ppm}$ is due to $-\mathrm{NH}_{2}$ group. The position of this singlet remains unchanged in the complexes. It shows that the $-\mathrm{NH}_{2}$ group is not taking part in complexation. Significant azomethine proton signal due to $\mathrm{HC}=\mathrm{N}$ was observed at $\delta 8.02 \mathrm{ppm}$ in Schiff base ligand. On complexation the position of this signal is shifted to $\delta 8.18-8.30 \mathrm{ppm}$. It indicates that azomethine nitrogen involved in coordination. The proton peak of $\mathrm{N}-\mathrm{H}$ group at $\delta 10.8-11.2 \mathrm{ppm}$ remains at same position in ligand and in the complexes which suggests that deprotonation do not occurred [19].

The ${ }^{13} \mathrm{C}$ NMR spectra revealed the presence of expected number of signals corresponding to different types of carbon atoms present in the compounds. The Schiff base ligand shows the signal at $\delta 21.42 \mathrm{ppm}$ due to car- 
bon atoms of methyl groups. On complexation no change has been observed. The spectra of the Schiff base ligand exhibits a strong band at $\delta 179.2 \mathrm{ppm}$ due to $\mathrm{C}=\mathrm{S}$ group. On complex formation the position of this band undergoes upfield shift to $\delta 171.9-172.5 \mathrm{ppm}$. This indicates that sulphur is involved in coordination.

\subsection{IR Spectra}

The IR absorption bands, which provide information about the formation of Schiff base ligand and the mode of coordination in its complexes, are given in Table 3. The ligand displays an intense band at $1590 \mathrm{~cm}^{-1}$ corresponding to $v(\mathrm{C}=\mathrm{N})$ stretching vibration. On complex formation, the position of $v(\mathrm{C}=\mathrm{N})$ band shows the negative shift which indicates that the nitrogen atom of azomethine group is coordinated to metal ion [20,21]. The spectum of the ligand shows a strong band at $820 \mathrm{~cm}^{-1}$ due to $v(\mathrm{C}=\mathrm{S})$ group. In the spectra of the complexes the position of this band suffers a downward shift suggesting coordination of the metal ion through sulphur atom of thiosemicarbazone group [22].

Moreover, the Schiff base ligand shows IR spectral bands at 1505,595 and $475 \mathrm{~cm}^{-1}$ due to pyridine ringstretching, in-plane-ring-bending and out-of-plane-ringbending vibrations, respectively. In the IR spectra of $\mathrm{Rh}$ (III) and Ir(III) complexes, these bands show substantial positive shift with fairly low intensity indicating the involvement of nitrogen atom of pyridine entity present in the ligand to central metal atom. On the other hand, in the IR spectra of Pd(II) and Pt(II) complexes the position of this band remain unchanged which indicates the presence of uncoordinated pyridine ring. This discussion reveals that the Schiff base ligand possesses five potential coordination sites (SNNNS) for $\operatorname{Rh}(\mathrm{III})$ and $\operatorname{Ir}(\mathrm{III})$ complexes and four potential coordination sites (SNNS) for $\mathrm{Pd}(\mathrm{II})$ and $\mathrm{Pt}(\mathrm{II})$ complexes. The complexes show the new bands in the range $345-405 \mathrm{~cm}^{-1}$ and $309-320$ $\mathrm{cm}^{-1}$ which may be due to $v(\mathrm{M}-\mathrm{N})$ and $v(\mathrm{M}-\mathrm{S})$ stretching vibrations, respectively [23]. The chloro complexes show the bands in the region $310-326 \mathrm{~cm}^{-1}$ corresponding $v(\mathrm{M}-\mathrm{Cl})[24]$.

\subsection{Magnetic Moments and Electronic Spectra}

\subsubsection{Pd(II) and Pt(II) Complexes}

The complexes are diamagnetic as expected for square planar $\mathrm{d}^{8}$ systems. The electronic spectra of the complexes under study display two bands at $357-381 \mathrm{~nm}$ and $523-537 \mathrm{~nm}$. These bands may be assigned to ${ }^{1} \mathrm{~A}_{1 \mathrm{~g}}$ $\rightarrow{ }^{1} \mathrm{~A}_{2 \mathrm{~g}}\left(v_{1}\right)$ and ${ }^{1} \mathrm{~A}_{1 \mathrm{~g}} \rightarrow{ }^{1} \mathrm{~B}_{1 \mathrm{~g}}\left(v_{2}\right)$ transitions, respectively. The electronic spectra of these complexes indicate the square planar geometry around the $\mathrm{Pd}(\mathrm{II})$ and $\mathrm{Pt}(\mathrm{II})$ ion $[25,26]$. By assuming a value of $\mathrm{F}_{2}=10 \mathrm{~F}_{4}=600$ for Slater-Condon interelectronic repulsion parameters for both $\mathrm{Pd}$ and $\mathrm{Pt}$, it is possible to calculate the value of $\Delta_{1}$ (Table 4) from the first spin allowed d-d transition. The splitting parameter increases in the expected order $\mathrm{Pt}>$ Pd.

\subsection{2. $R$ h(III) and Ir(III) Complexes}

The complexes are also diamagnetic. The electronic spectrum of $\mathrm{Rh}(\mathrm{III})$ complex displays bands at $357 \mathrm{~nm}, 478$ $\mathrm{nm}$ and $572 \mathrm{~nm}$. These bands may be assigned ${ }^{1} \mathrm{~A}_{1 \mathrm{~g}} \rightarrow$ ${ }^{3} \mathrm{~T}_{1 \mathrm{~g}},{ }^{1} \mathrm{~A}_{1 \mathrm{~g}} \rightarrow{ }^{1} \mathrm{~T}_{1 \mathrm{~g}}$ and ${ }^{1} \mathrm{~A}_{1 \mathrm{~g}} \rightarrow{ }^{1} \mathrm{~T}_{2 \mathrm{~g}}$, transitions respectively corresponding to an octahedral geometry [27]. The

Table 2. NMR spectral data ( $\delta \mathrm{ppm})$ of $\mathrm{Pd}(\mathrm{II}), \mathrm{Pt}(\mathrm{II}), \mathrm{Rh}(\mathrm{III})$ and $\mathrm{Ir}(\mathrm{III})$ complexes with investigated ligand (L).

\begin{tabular}{|c|c|c|c|c|c|c|c|}
\hline \multirow{2}{*}{ Compounds } & \multicolumn{4}{|c|}{${ }^{1} \mathrm{H}$ NMR } & \multicolumn{3}{|c|}{${ }^{13} \mathrm{C}$ NMR } \\
\hline & $\delta\left(\mathrm{NH}_{2}\right)$ & $\delta(\mathrm{NH})$ & $\delta(\mathrm{HC}=\mathrm{N})$ & $\delta\left(\mathrm{CH}_{3}\right)$ & $\delta(\mathrm{C}=\mathrm{N})$ & $\delta(\mathrm{C}=\mathrm{S})$ & $\delta\left(\mathrm{CH}_{3}\right)$ \\
\hline Ligand (L) & 2.48 & 10.9 & 8.02 & 2.27 & 165.1 & 179.2 & 21.42 \\
\hline$[\mathrm{Pd}(\mathrm{L})] \mathrm{Cl}_{2}$ & 2.49 & 11.2 & 8.25 & 2.29 & 160.5 & 171.9 & 21.40 \\
\hline$[\mathrm{Pt}(\mathrm{L})] \mathrm{Cl}_{2}$ & 2.48 & 11.0 & 8.18 & 2.26 & 161.2 & 172.5 & 21.42 \\
\hline$[\mathrm{Rh}(\mathrm{L}) \mathrm{Cl}] \mathrm{Cl}_{2}$ & 2.47 & 10.8 & 8.22 & 2.29 & 160.8 & 172.1 & 21.41 \\
\hline$[\mathrm{Ir}(\mathrm{L}) \mathrm{Cl}] \mathrm{Cl}_{2}$ & 2.49 & 10.9 & 8.30 & 2.30 & 161.6 & 171.3 & 21.40 \\
\hline
\end{tabular}

Table 3. IR band assignment ( $\left.\mathrm{cm}^{-1}\right)$ of $\mathrm{Pd}(\mathrm{II}), \mathrm{Pt}(\mathrm{II}), \mathrm{Rh}(\mathrm{III})$ and $\mathrm{Ir}(\mathrm{III})$ complexes with investigated ligand (L).

\begin{tabular}{cccccc}
\hline Compounds & $v(\mathrm{C}=\mathrm{N})$ & $v(\mathrm{C}=\mathrm{S})$ & Pyridine ring & $v(\mathrm{M}-\mathrm{N})$ & $v(\mathrm{M}-\mathrm{S})$ \\
\hline Ligand $(\mathrm{L})$ & $1590 \mathrm{~ms}$ & $820 \mathrm{~s}$ & $1505 \mathrm{vs}, 595 \mathrm{mw}, 475 \mathrm{mw}$ & - & - \\
{$[\mathrm{Pd}(\mathrm{L})] \mathrm{Cl}_{2}$} & $1565 \mathrm{~s}$ & $802 \mathrm{~ms}$ & $1505 \mathrm{vs}, 595 \mathrm{mw}, 475 \mathrm{mw}$ & $390 \mathrm{sh}$ & $315 \mathrm{w}$ \\
{$[\mathrm{Pt}(\mathrm{L})] \mathrm{Cl}_{2}$} & $1558 \mathrm{~s}$ & $795 \mathrm{~m}$ & $1505 \mathrm{vs}, 595 \mathrm{mw}, 475 \mathrm{mw}$ & $345 \mathrm{~ms}$ & $309 \mathrm{~m}$ \\
{$[\mathrm{Rh}(\mathrm{L}) \mathrm{Cl}] \mathrm{Cl}_{2}$} & $1571 \mathrm{mw}$ & $812 \mathrm{sh}$ & $1552 \mathrm{~s}, 613 \mathrm{w}, 530 \mathrm{mw}$ & $405 \mathrm{w}$ & $317 \mathrm{sh}$ \\
{$[\mathrm{Ir}(\mathrm{L}) \mathrm{Cl}] \mathrm{Cl}_{2}$} & $1660 \mathrm{~m}$ & $790 \mathrm{~m}$ & $1529 \mathrm{w}, 630 \mathrm{w}, 513 \mathrm{~m}$ & $370 \mathrm{~m}$ & $320 \mathrm{mw}$ \\
\hline
\end{tabular}

$\mathrm{m}=$ medium, $\mathrm{ms}=$ medium strong, $\mathrm{vs}=$ very strong, $\mathrm{sh}=$ sharp, $\mathrm{w}=$ weak, $\mathrm{s}=$ strong, $\mathrm{mw}=$ medium weak. 
$\mathrm{B}$ and $\mathrm{Dq}$ values are calculated from the positions of their electronic bands using the following equations:

$$
v_{1}=10 \mathrm{Dq}-4 \mathrm{~B}+\frac{86(\mathrm{~B})^{2}}{10 \mathrm{Dq}}, \quad v_{2}=10 \mathrm{Dq}+12 \mathrm{~B}+\frac{2(\mathrm{~B})^{2}}{10 \mathrm{Dq}} \text {. }
$$

The decrease in B values from the free ion value suggests that there is a considerable orbital overlap with strong covalency in the metal ligand $\sigma$ bond [28].

The electronic spectrum of the iridium(III) complex displays bands at $292 \mathrm{~nm}$ and $324 \mathrm{~nm}$, which may be assigned to ${ }^{1} \mathrm{~A}_{1 \mathrm{~g}} \rightarrow{ }^{1} \mathrm{~T}_{1 \mathrm{~g}}\left(v_{1}\right)$ and ${ }^{1} \mathrm{~A}_{1 \mathrm{~g}} \rightarrow{ }^{1} \mathrm{~T}_{2 \mathrm{~g}}\left(v_{2}\right)$ transitions in order of increasing energy. These transitions are used to evaluate the ligand field parameters (Table 4). The values of these ligand field parameters are compared with those reported for other iridium(III) complexes involving similar donor atoms [29].

\subsection{Suggested Structure of the Complexes}

On the basis of above mentioned discussions using elemental analysis, mass, NMR and IR spectral studies the following (Figure 2) structure may be suggested for the complexes.

\subsection{Biological Results and Discussion}

The antimicrobial screening data show that the metal chelates exhibit a higher inhibitory effect than the free ligand and metal salts (Tables 5 and 6). The increased activity of the metal chelates can be explained based on the chelation theory [30]. The chelation reduces the polarity of the metal atom mainly because of the partial sharing of its positive charge with the donor groups and possible $p$ electron delocalization with in the whole chelation ring. The chelation ring increases the lipophillic nature of the central atom which subsequently favours its permeation through the lipid layer of the cell memberane [31]. The enhanced activity of the complexes can also be explained on the basis of their high solubility fineness of the particles, size of the metal ion and the presence of bulkier organic moieties. The mode of action may involve the formation of a hydrogen bond through the azomethane nitrogen atom with the active centers of the cell constituents, resulting in interference with the normal cell process. The variation in the effectiveness of different compounds against different organisms depend either on the impermeability of the cells of the microbes or difference in ribosomes of microbial cells. It has also been proposed that concentration plays a vital role in increasing the degree of inhibition; as the concentration increases, the activity increases [32].

The results of fungicidal screening (Figure 3) show that $\mathrm{Pd}(\mathrm{II})$ complex is highly active as compared to free

Table 4. Electronic spectral bands $\left(\mathrm{cm}^{-1}\right)$ and ligand field parameters of the complexes.

\begin{tabular}{|c|c|c|c|c|c|c|c|}
\hline Complexes & $\lambda_{\max }(\mathrm{nm})$ & $\operatorname{Dq}\left(\mathrm{cm}^{-1}\right)$ & $\mathrm{B}\left(\mathrm{cm}^{-1}\right)$ & $\mathrm{C}\left(\mathrm{cm}^{-1}\right)$ & $\mathrm{B}$ & $v_{2} / v_{1}$ & $\Delta_{1}\left(\mathrm{~cm}^{-1}\right)$ \\
\hline$[\mathrm{Pd}(\mathrm{L})] \mathrm{Cl}_{2}$ & 537,357 & - & - & - & - & - & 20421 \\
\hline$[\mathrm{Pt}(\mathrm{L})] \mathrm{Cl}_{2}$ & 523,381 & - & - & - & - & - & 20920 \\
\hline$[\mathrm{Rh}(\mathrm{L}) \mathrm{Cl}] \mathrm{Cl}_{2}$ & $572,478,357$ & 2265 & 444 & 1775 & 0.62 & 1.34 & - \\
\hline$[\mathrm{Ir}(\mathrm{L}) \mathrm{Cl}] \mathrm{Cl}_{2}$ & 324,292 & 3085 & 212 & 850 & 0.32 & 1.11 & - \\
\hline
\end{tabular}
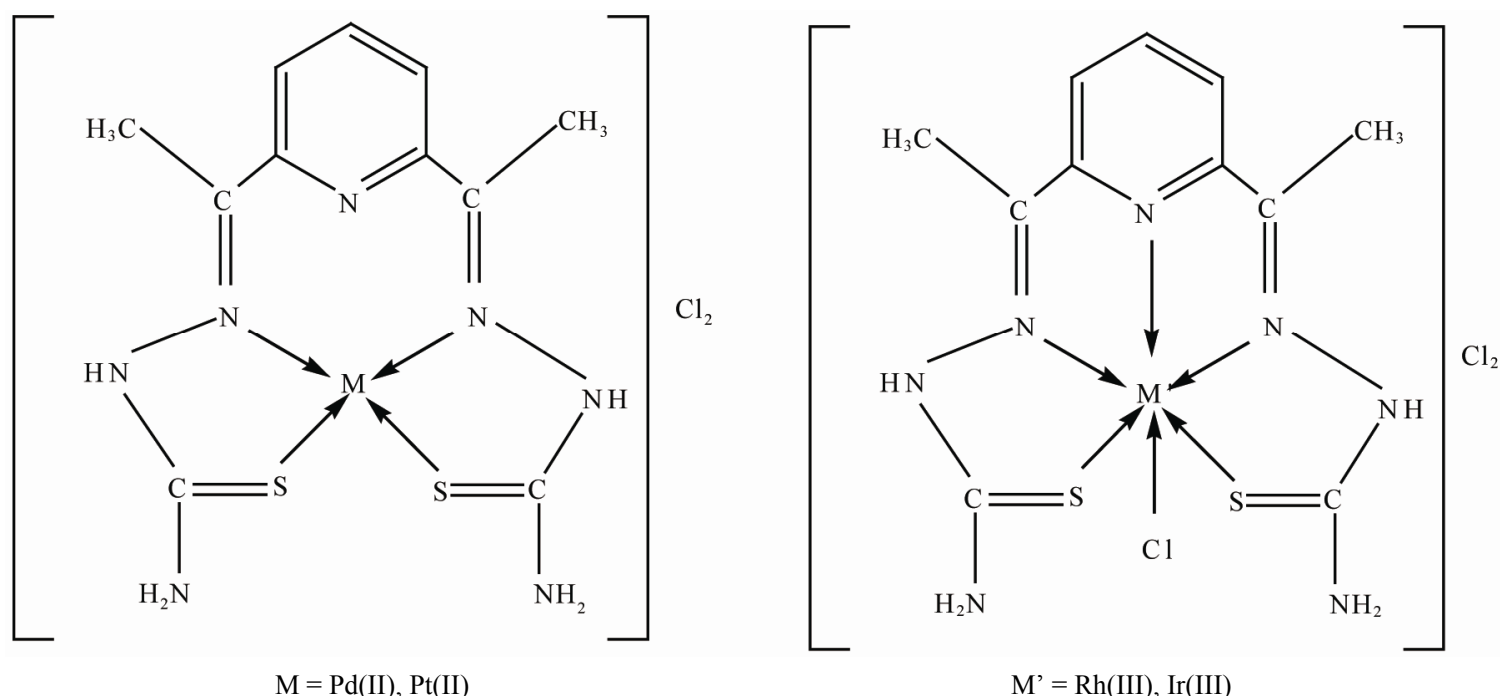

Figure 2. Suggested structure of the complexes. 
Table 5. Antifungal screening data of investigated ligand (L) and its $\mathrm{Pd}(\mathrm{II}), \mathrm{Pt}(\mathrm{II}), \mathrm{Rh}(\mathrm{III}), \mathrm{Ir}(\mathrm{III})$ complexes.

\begin{tabular}{|c|c|c|c|c|c|c|c|c|c|c|}
\hline \multirow[t]{3}{*}{ Compound no. } & \multirow[t]{3}{*}{ Compounds } & \multicolumn{9}{|c|}{ Fungal Inhibition (\%) (conc. in $\mu \mathrm{g} \cdot \mathrm{ml}^{-1}$ ) } \\
\hline & & \multicolumn{3}{|c|}{ Aspergillus niger } & \multicolumn{3}{|c|}{ Aspergillus fumigates } & \multicolumn{3}{|c|}{ Fusarium odum } \\
\hline & & 100 & 200 & 300 & 100 & 200 & 300 & 100 & 200 & 300 \\
\hline 1. & Ligand (L) & 32 & 46 & 58 & 38 & 57 & 68 & 29 & 35 & 49 \\
\hline 2. & {$[\mathrm{Pd}(\mathrm{L})] \mathrm{Cl}_{2}$} & 51 & 67 & 85 & 56 & 78 & 89 & 49 & 64 & 75 \\
\hline 3. & {$[\mathrm{Pt}(\mathrm{L})] \mathrm{Cl}_{2}$} & 49 & 62 & 80 & 54 & 75 & 87 & 45 & 65 & 72 \\
\hline 4. & {$[\mathrm{Rh}(\mathrm{L}) \mathrm{Cl}] \mathrm{Cl}_{2}$} & 46 & 59 & 77 & 50 & 67 & 82 & 40 & 59 & 70 \\
\hline 5. & {$[\operatorname{Ir}(\mathrm{L}) \mathrm{Cl}] \mathrm{Cl}_{2}$} & 48 & 57 & 71 & 52 & 70 & 85 & 39 & 49 & 66 \\
\hline 6. & $\mathrm{PdCl}_{2}$ & 45 & 50 & 65 & 46 & 62 & 78 & 35 & 43 & 59 \\
\hline 7. & $\mathrm{PtCl}_{2}$ & 42 & 54 & 62 & 49 & 60 & 76 & 35 & 40 & 57 \\
\hline 8. & $\mathrm{RhCl}_{3}$ & 39 & 47 & 64 & 39 & 55 & 69 & 30 & 41 & 52 \\
\hline 9. & $\mathrm{IrCl}_{3}$ & 34 & 45 & 59 & 41 & 59 & 73 & 27 & 39 & 50 \\
\hline 10. & Amphotericin-B & 55 & 72 & 89 & 59 & 81 & 92 & 50 & 69 & 80 \\
\hline
\end{tabular}

Table 6. Antibacterial screening data of investigated ligand (L) and its $\mathrm{Pd}(\mathrm{II}), \mathrm{Pt}(\mathrm{II}), \mathrm{Rh}(\mathrm{III}), \mathrm{Ir}(\mathrm{III})$ complexes.

\begin{tabular}{|c|c|c|c|c|c|c|c|}
\hline \multirow[t]{3}{*}{$\begin{array}{l}\text { Compund } \\
\text { no. }\end{array}$} & \multirow[t]{3}{*}{ Compounds } & \multicolumn{6}{|c|}{$\begin{array}{l}\text { Diameter of Inhibition Zone } \\
(\mathrm{mm})\left(\text { conc. in } \mu \mathrm{g} \cdot \mathrm{ml}^{-1}\right)\end{array}$} \\
\hline & & \multicolumn{3}{|c|}{ Staphyloccocus aureus } & \multicolumn{3}{|c|}{ Escherichia coli } \\
\hline & & 100 & 200 & 300 & 100 & 200 & 300 \\
\hline 1. & Ligand (L) & 19 & 25 & 31 & 20 & 29 & 33 \\
\hline 2. & {$[\mathrm{Pd}(\mathrm{L})] \mathrm{Cl}_{2}$} & 25 & 29 & 35 & 24 & 31 & 38 \\
\hline 3. & {$[\mathrm{Pt}(\mathrm{L})] \mathrm{Cl}_{2}$} & 28 & 31 & 39 & 27 & 34 & 41 \\
\hline 4. & {$[\mathrm{Rh}(\mathrm{L}) \mathrm{Cl}] \mathrm{Cl}_{2}$} & 20 & 26 & 33 & 22 & 29 & 35 \\
\hline 5. & {$[\operatorname{Ir}(\mathrm{L}) \mathrm{Cl}] \mathrm{Cl}_{2}$} & 22 & 27 & 32 & 19 & 26 & 30 \\
\hline 6. & $\mathrm{PdCl}_{2}$ & 17 & 22 & 26 & 15 & 19 & 25 \\
\hline 7. & $\mathrm{PtCl}_{2}$ & 18 & 21 & 25 & 17 & 22 & 29 \\
\hline 8. & $\mathrm{RhCl}_{3}$ & 18 & 24 & 29 & 19 & 24 & 31 \\
\hline 9. & $\mathrm{IrCl}_{3}$ & 19 & 22 & 28 & 18 & 21 & 26 \\
\hline 10. & Streptomycin & 26 & 30 & 36 & 29 & 35 & 40 \\
\hline
\end{tabular}

ligand and metal salt against all the fungal species. The order of the fungal and bacterial growth inhibition of the compounds is shown in Figures $\mathbf{4}$ and $\mathbf{5}$.

\section{CONCLUSION}

On the basis of NMR, IR and UV palladium(II) and platinum(II) complexes were found with square planar geometry while the rhodium(III) and iridium(III) complexes were found with octahedral geometry. The antifungal and antibacterial screening of the compounds indicates that the $\mathrm{Pd}(\mathrm{II})$ complex is highly active while the other metal complexes show moderate activity in comparison of the free ligand and metal salts.

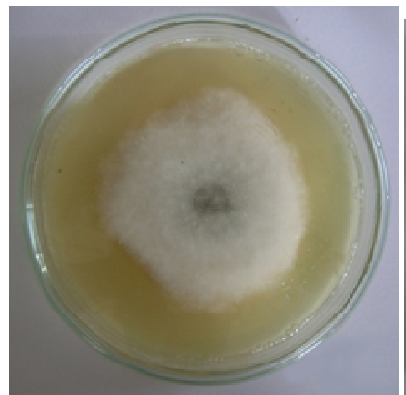

(a)

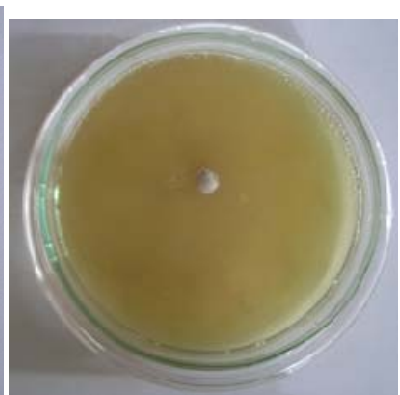

(b)

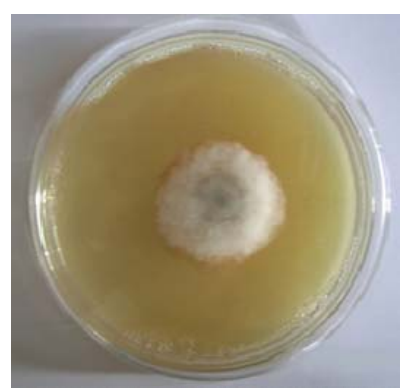

(c)

Figure 3. Antifungal activities of compounds against Aspergillus fumigatus (a) Ligand; (b) $[\mathrm{Pd}(\mathrm{L})] \mathrm{Cl}_{2}$; (c) $\mathrm{PdCl}_{2}$.

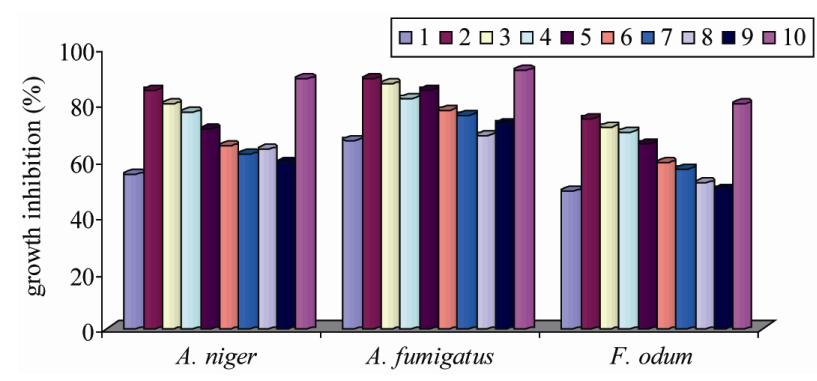

Figure 4. Graphical representation of antifungal activities of the compounds. 


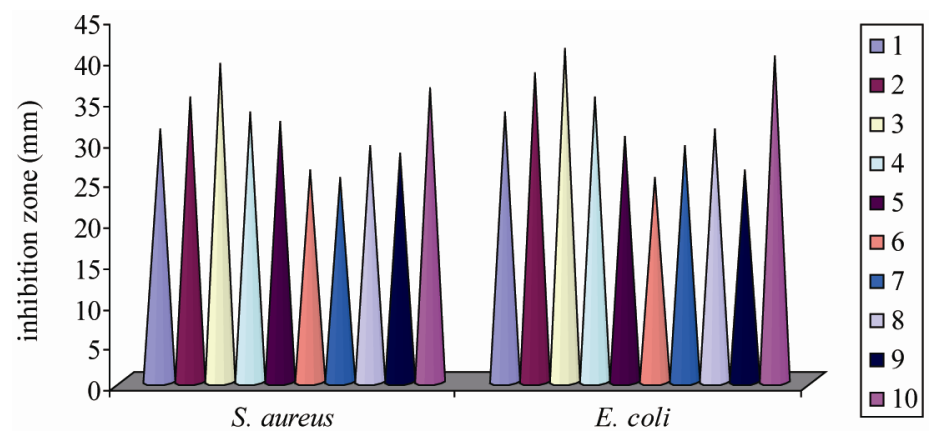

Figure 5. Graphical representation of antibacterial activities of the compounds.

\section{ACKNOWLEDGEMENTS}

Authors are thankful to the DRDO New Delhi for financial support and Delhi University for recording IR spectra.

\section{REFERENCES}

[1] Mishra, D., Naskar, S., Drew, M.G.B. and Chattopadhyay, S.K. (2006) Synthesis, spectroscopic and redox properties of some ruthenium(II) thiosemicarbazone complexes: Structural description of four of these complexes. Inorganica Chimica Acta, 359, 585-592. doi:10.1016/j.ica.2005.11.001

[2] Agarwal, R.K. and Prasad, S. (2005) Synthesis and spectral investigations of some platinum metals ions coordination compounds of 4 [N-(furan-2'-carboxalidene)amino] antipyrine thiosemicarbazone and $4\left[\mathrm{~N}-\left(3^{\prime}, 4{ }^{\prime}, 5^{\prime}\right.\right.$-trime-thoxybenzalidene) amino] antipyrine thiosemicarbazone. Turkish Journal of Chemistry, 29, 289-297.

[3] Patil, S.A., Naik, V.H., Kulkarni A.D. and Badami P.S. (2010) DNA cleavage, antimicrobial, spectroscopic and fluorescence studies of $\mathrm{Co}(\mathrm{II}), \mathrm{Ni}(\mathrm{II})$ and $\mathrm{Cu}(\mathrm{II})$ complexes with SNO donor coumarin Schiff bases. Spectrochimica Acta A, 75, 347-354. doi:10.1016/j.saa.2009.10.039

[4] Sharma, K., Singh, R., Fahmi, N. and Singh, R.V. (2010) Microwave assisted synthesis, characterization and biological evaluation of palladium and platinum complexes with azomethines. Spectrochimica Acta A, 75, 422-427. doi:10.1016/j.saa.2009.10.052

[5] Al-Amiery, A.A., Al-Majedy, Y.K., Abdulreazak, H. and Abood, H. (2011) Synthesis, characterization, theoretical crystal structure, and antibacterial activities of some transition metal complexes of the thiosemicarbazone (Z)-2(pyrrolidin-2-ylidene)hydrazinecarbothioamide. Bioinorganic Chemistry and Applications, 2011, 1-6, Article ID 483101.

[6] Wiecek, J., Kovala-Demertzi, D., Ciunik, Z., Zervou, M. and Demertzis, M.A. (2010) Diorganotin complexes of a thiosemicarbazone, synthesis: Properties, x-ray crystal structure, and antiproliferative activity of diorganotin complexes. Bioinorganic Chemistry and Applications, 2010, 1-9, Article ID 867195.

[7] Ferraz, K.O., Wardell, S.M.S.V., Wardell, J.L., Louro,
S.R.W. and Beraldo, H. (2009) Copper(II) complexes with 2-pyridineformamide-derived thiosemicarbazones: Spectral studies and toxicity against Artemia salina. Spectrochimica Acta A, 73, 140-145. doi:10.1016/j.saa.2009.02.020

[8] Graminha, A.E., Batista, A.A., Mendes, I.C., Teixeira, L.R. and Beraldo, H. (2008) Ruthenium(II) complexes containing 2-pyridineformamide- and 2-benzoylpyridinederived thiosemicarbazones and $\mathrm{PPh}_{3}$ : NMR and electrochemical studies of cis-trans-isomerization. Spectrochimica Acta A, 69, 1277-1282. doi:10.1016/j.saa.2007.07.005

[9] Raja, N. and Ramesh, R. (2010) Mononuclear ruthenium(III) complexes containing chelating thiosemicarbazones: Synthesis, characterization and catalytic property. Spectrochimica Acta A, 75, 713-718. doi:10.1016/j.saa.2009.11.044

[10] Bakir, J.A. and Dissouky, E.I. (2005) Synthesis, spectroscopic and the biological activity studies of thiosemicarbazones containing ferrocene and their copper(II) complexes. Journal of Coordination Chemistry, 58, 10291038. doi:10.1080/00958970500096975

[11] Chandra, S., Tyagi, M. and Agrawal, S. (2010) Spectral and antimicrobial studies on tetraaza macrocyclic complexes of $\mathrm{Pd}^{\mathrm{II}}, \mathrm{Pt}^{\mathrm{II}}, \mathrm{Rh}^{\mathrm{III}}$ and $\mathrm{Ir}^{\mathrm{III}}$ metal ions. Journal of Saudi Chemical Society, 15, 49-54. doi:10.1016/j.jscs.2010.09.005

[12] Chandra, S. and Kumar, A. (2007) Spectral studies on $\mathrm{Co}(\mathrm{II}), \mathrm{Ni}$ (II) and $\mathrm{Cu}$ (II) complexes with thiosemicarbazone $\left(\mathrm{L}^{1}\right)$ and semicarbazone $\left(\mathrm{L}^{2}\right)$ derived from 2-acetyl furan. Spectrochimica Acta A, 66, 1347-1351. doi:10.1016/j.saa.2006.04.047

[13] Kumar, U. and Chandra, S. (2010) Biological active cobalt(II) and nickel(II) complexes of 12-membered hexaaza $\left[\mathrm{N}_{6}\right]$ macrocyclic ligand: Synthetic and spectroscopic aspects. E-Journal of Chemistry, 7, 1238-1245. doi: $10.1155 / 2010 / 518723$

[14] Chandra, S., Verma, S., Dev, U. and Joshi, N. (2009) Tetraaza macrocyclic complexes: Synthesis, spectral and antimicrobial studies. Journal of Coordination Chemistry, 62, 1327-1335. doi:10.1080/00958970802521076

[15] Refat, M.S., Chandra, S. and Tyagi, M. (2010) Spectroscopic, thermal and biocidal studies on $\mathrm{Mn}(\mathrm{II}), \mathrm{Co}(\mathrm{II})$, $\mathrm{Ni}(\mathrm{II})$ and $\mathrm{Cu}(\mathrm{II})$ complexes of tridentate ligand having 
semicarbazone moieties. Journal of Thermal Analysis and Calorimetry, 61, 261-267. doi:10.1007/s10973-009-0397-5

[16] Agarwal, R.K., Singh, L. and Sharma, P. (2006) Synthesis, spectral and biological properties of copper(II) complexes of thiosemicarbazones of schiff bases derived from 4-aminoantipyrine and aromatic aldehyde. Bioinorganic Chemistry and Applications, 2006, 1-10, Article ID 59509.

[17] Chandra, S., Raizada, S., Tyagi, M. and Sharma, P. (2008) Spectroscopic and biological approach of $\mathrm{Ni}(\mathrm{II})$ and $\mathrm{Cu}(\mathrm{II})$ complexes of 2-pyridinecarboxald-ehyde thiosemicarbazone. Spectrochimica Acta A, 69, 816-821. doi:10.1016/j.saa.2007.05.033

[18] Sharma, K., Singh, R. and Fahmi, N. (2010) Microwave assisted synthesis, characterization and biological evaluation of palladium and s with azomethines. Spectrochimica Acta A, 75, 422-427. doi:10.1016/j.saa.2009.10.052

[19] Wehrli, F.W., Marchand, A.P. and Wehrli, S. (1988) Interpretation of Carbon- ${ }^{13}$ NMR Spectra. 2nd Edition, Wiley, New York.

[20] Deepa, K.P. and Aravindakshan, K.K. (2000) Synthesis, characterizationand thermal studies of thiosemicarbazones of N-methylandN-ethylacetoacetanilide. Synthesis and Reactivity in Inorganic, Metal-Organic, and NanoMetal Chemistry, 30, 1601-1616.

[21] Joseph, M., Sreekanth, A., Suni, V. and Kurup, M.R.P. (2006) Spectral characterization of iron(III) complexes of 2-benzoylpyridineN(4)-substituted thiosemicarbazones. Spectrochimica Acta A, 64, 637-641. doi:10.1016/j.saa.2005.07.067

[22] Singh, R.V., Biyala, M.K. and Fahmi, N. (2005) Important properties of sulfur-bonded organoboron(III) complexes with biologically potent ligands. Phosphorus, Sulfur and Silicon and the Related Elements, 180, 425-434. doi:10.1080/104265090509225

[23] Chandra, S. and Gupta, L.K. (2005) EPR, masss, IR, electronic and magnetic studies on copper(II) complexes of semicarbazones and thiosemicarbazones. Spectrochi- mica Acta A, 61, 269-275.

[24] Bailey, R.A., Kozak, S.L., Michelson, T.W. and Mills, W.N. (1971) Infrared spectra of complexes of the thio ions. Coordination Chemistry Reviews, 6, 407-445.

[25] Singh, S., Bharti, N., Naqvi, F. and Azam, A. (2004) Synthesis, characterization and in vitro antiamoebic activity of 5 nitrothiophene-2-carboxaldehyde thiosemicarbazones and their Palladium(II) and Ruthenium(II) complexes. European Journal of Medicinal Chemistry, 39, 459-465.

[26] Chandra, S., Raizada, S. and Rani, S. (2008) Structural and spectral studies of palladium(II) and platinum(II) complexes derived from $N, N, N, N$-tetradentate macrocyclic ligands. Spectrochimica Acta A, 71, 720-724.

[27] Jorgensen, C.K. (1964) Absorption Spectra and Chemical Bonding in Complexes. Pergamon Press, London.

[28] Chandra, S. and Singh, R. (1988) Pd(II), Pt(II), Rh(III), $\mathrm{Ir}(\mathrm{III})$ and $\mathrm{Ru}(\mathrm{III})$ complexes of some nitrogen-oxygen donor ligands. Indian Journal of Chemistry, 27, 417-420.

[29] Chandra, S., Kumar, S. and Rani, S. (2011) Synthesis, structural, spectral, thermal and antimicrobial studies of palladium(II), platinum(II), ruthenium(III) and iridium(III) complexes derived from $N, N, N, N$-tetradentate macrocyclic ligand. Spectrochimica Acta A, 78, 1507-1514.

[30] El-Behery, M. and El-Twigry, H. (2007) Synthesis, magnetic, spectral, and antimicrobial studies of $\mathrm{Cu}(\mathrm{II}), \mathrm{Ni}(\mathrm{II})$ $\mathrm{Co}(\mathrm{II}), \mathrm{Fe}(\mathrm{III})$, and $\mathrm{UO}_{2}$ (II) complexes of a new Schiff base hydrazone derived from 7-chloro-4-hydrazinoquinoline. Spectrochimica Acta A, 66, 28-36.

[31] Tyagi, M. and Chandra, S. (2012) Chromium(III) and manganese(II) complexes of macrocyclic ligand containing thiosemicarbazide moiety: Spectroscopic and biological studies. Journal of the Indian Chemical Society, 89, 147-154.

[32] Chandra, S. and Tyagi, M. (2008) Ni(II), Pd(II) and Pt(II) complexes with ligand containing thiosemicarbazone and semicarbazone moiety: Synthesis, characterization and biological investigation. Journal of the Serbian Chemical Society, 73, 727-734. 